\title{
Rhaphidophora petrieana - a new aroid liane from tropical Queensland; with a synopsis of the Australian Araceae-Monstereae
}

\author{
A. Hay
}

\begin{abstract}
Hay, A. (Royal Botanic Gardens Sydney, Mrs Macquaries Road, Sydney, NSW, Australia 2000) 1993. Rhaphidophora petrieana - a new aroid liane from tropical Queensland; with a synopsis of the Australian Araceae-Monstereae. Telopea 5(2):293-300. Rhaphidophora petrieana (AraceaeMonstereae) is described and illustrated. A synopsis of the tribe Monstereae in Australia and keys to the genera and species are provided.
\end{abstract}

\section{Introduction}

The tribe Monstereae is one of only two pantropical tribes of Araceae, the other being the Lasieae (Hay 1988, 1992). Monstereae are most closely allied to tropical amphitrans-Pacific Spathiphylleae, including Spathiphyllum (itself amphi-trans-Pacific) and Holochlamys (endemic to New Guinea). Since Engler, these two tribes have generally been considered to make up the subfamily Monsteroideae, though Bogner \& Nicolson (1991) add West Malesian Anadendreae and Neotropical Heteropsideae in their revised Englerian classification. However, Grayum (1990) drew attention to difficulty in separating Monsteroideae from Pothoideae, and merged them, a move which Bogner \& Nicolson have not followed and one which is regarded here as premature rather than incorrect.

Monstereae was last fully revised by Engler \& Krause (1908) and since then only two generic monographs have been carried out, those of Malesian Amydrium (Nicolson 1968) and Neotropical Monstera (Madison 1977). Grayum (1990), Bogner \& Nicolson (1991) and Hay \& Mabberley (1991) have, with minor amendments, followed Englerian generic concepts for this tribe. However, although additional information has been provided on vegetative (French 1987a, 1987b, 1988; French \& Tomlinson 1981; Nicolson 1960), pollen (Grayum 1984, 1990), floral (Eyde et al. 1967; French 1985, 1986; Carvell 1989), and seed (Madison \& Tiffney 1976) anatomy, generic concepts remain problematic and particularly irksome in the Orient in the absence of further monographs. The historical bases for generic limits lie primarily in ovule number, placentation and albuminosity of the seed, while a wealth of information relating to vegetative architecture and to germination, establishment and climbing behaviour, mostly inaccessible in the herbarium, remains largely untapped [but see Blanc (1978, 1981); Hay (1986, 1990); Hay \& Mabberley (1991); Madison (1977); and Ray (19871990) for some discussion of variation in germination and/or climbing characteristics in scandent aroids]. Hay (1990) has noted that generic limits in the oriental genera based on gynoecial and seed characters are not only blurred but also cut across suites of complex vegetative characteristics and that re-evaluation is required in order to propose more firmly where homoplasy may exist.

The scheme of plant architectural models drawn up by Hallé \& Oldeman (1970) and Hallé, Oldeman \& Tomlinson (1978) has proved to have some practical applicability to Malesian and Australasian Monstereae (Hay 1986, 1990; Hay \& Mabberley 1991), 
at least with the less leptocaul species. For the Australian species the relevant models are Chamberlain's, in which a clinging sympodial orthotropic axis flowers terminally, and Stone's, in which a clinging and apparently monopodial (if undamaged) orthotropic axis bears free sympodial lateral spreading but distally orthotropic shoots bearing terminal inflorescences. [However, Scarrone's model, differing from Stone's in having endogenously rhythmic growth, may apply in some cases - further observations are required.] More or less abrupt metamorphoses from juvenile to adult habit have been recorded for some Monstereae (see Madison 1977; Ray 1990) commonly involving a shingle-leaved juvenile phase with short petioles and laminas appressed to the substrate and an adult long-petioled and hanging-bladed phase (e.g. Malesian Rhaphidophora korthalsii Schott). Such is not yet recorded for Australian species, though R. pachyphylla K. Krause from New Guinea and Northern Queensland appears to be a persistently juvenile shingle-leaved species. The remainder simply enlarge into maturity without sudden or conspicuous alteration of habit, other than the emission of free lateral branches in some cases.

\section{Key to the genera of Araceae-Monstereae in Australia}

1 Ovule solitary, basal; seeds exalbuminous …................................... Scindapsus

1 Ovules few to many; seeds albuminous

2 Ovules numerous; stigmas punctate; seeds minute

Rhaphidophora

2 Ovules two to few; stigmas mostly slit-like; seeds stony, over $2 \mathrm{~mm}$ long

Epipremnum

As the generic characters are somewhat obscure, and current generic concepts probably inadequate reflections of phylogenetic relationship, a single key to the species of Australian Monstereae is given. It is necessary, at regional level, to distinguish $R$. petrieana, described below, not only from other Australian Rhaphidophora species but also from other easily confused members of the Monstereae not hitherto recorded in formal Australian botanical literature. A synopsis of those species is therefore given. Descriptions and exsiccatae will appear elsewhere, in a full account of the Araceae in Australia.

\section{Field key to the species of Araceae-Monstereae in Australia}

1 Leaf blades very broadly ovate, appressed to substrate, with the petiole much shorter than the blade and the sheath ligulate Rhaphidophora pachyphylla

1 Not so

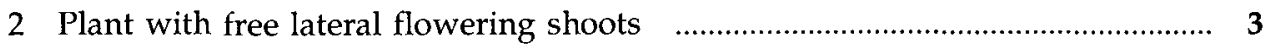

2 Inflorescences borne on adherent climbing shoots .............................................. 4 
3 Leaf sheath persistent; massive climber with internodes on adherent shoots to c. $30 \mathrm{~cm}$ long; leaf blades to c. $60 \mathrm{~cm}$, oblong-ovate; spadix to c. $25 \mathrm{~cm}$ long, sessile; stigmas slit-like, sessile

Scindapsus altissimus

3 Leaf sheath degrading to fibres; climber of lesser dimensions; internodes on adherent shoots a few centimetres long; leaf blades ovate- lanceolate, seldom exceeding $35 \mathrm{~cm}$ in length; spadix c. $8 \mathrm{~cm}$ long, stipitate; stigmas punctate, raised

Rhaphidophora petrieana

4 Leaf blades pinnatifid (juveniles entire), internodes with longitudinal crests, finer venation reticulate

Epipremnum pinnatum

4 Leaf blades entire, internodes crestless, all venation striate 5

5 Leaf sheath persistent; stigmas usually slit-like (sometimes some or many punctate ones in a spadix), always sessile; plants associated with swamps or permanent water

Epipremnum amplissimum

5 Leaf sheath quickly becoming papery-fibrous, thence usually deciduous; stigmas punctate, raised; rainforest plants

Rhaphidophora australasica

\section{Rhaphidophora}

Rhaphidophora Hassk., 25 Beibl. 1: 11 (1842); Bentham, Fl. Aust. 7: 156 (1878); Bailey, Queensland Fl. 5: 1697 (1902); Engler \& Krause in Engler, Pflanzenreich 37 (IV.23.B): 17 (1908). TYPE: R. lacera Hassk., nom. superfl. ( $\equiv$ R. pertusa (Roxb.) Schott; basionym Pothos pertusa Roxb.).

The typification of Rhaphidophora has been settled by Nicolson (1987). Thitherto it was questionable whether Rhaphidophora was distinct (for nomenclatural rather than taxonomic reasons) from Epipremnum [see Bakhuizen van den Brink (1958); Nicolson (1978)]. Hasskarl had based the description of $R$. lacera on specimens of what is currently called Epipremnum pinnatum (L.) Engler, but included in its synonymy Roxburgh's Pothos pertusa (1820), which conforms to current concepts of Rhaphidopho$r a$, thus rendering $R$. lacera illegitimate. The issue had concerned the desirability of whether typification of a generic name should reflect its author's circumscription in the protologue, or follow automatic typification (i.e. that of the legitimate name): see Nicolson (1978). The type of $P$. pertusa must be used as the type of $R$. lacera (on the basis of automatic typification - Art. 7.13 of the International Code of Botanical Nomenclature), and hence the type species of Rhaphidophora is distinct from Epipremnum pinnatum. Whether Epipremnum and Rhaphidophora are taxonomically distinct remains to be seen.

\section{Rhaphidophora petrieana $A$. Hay sp. nov.}

$\mathrm{Ab}$ aliis speciebus Australasicis Rhaphidophorae inflorescentiis surculis lateralibus liberis insidentibus, spadice stipitato, stylo conoideo differt.

TyPe: QueEnsLAnd: National Park Reserve 904, Palmerston Highway, B. Gray 2862, 30 November 1982, fl. (QRS!, holo). 
'Rhaphidophora sp. aff. australasica (Qld)', Jones \& Gray, Climbing Pl. Australia: 317, un-numbered plate p. 322 (1988).

Homophyllous liane climbing to c. $20 \mathrm{~m}$ tall on the trunks of rainforest trees; clinging axes monopodial, emitting free lateral sympodial flowering shoots; leaves simple, entire, mid-green above, paler below, narrowly ovate to lanceolate, somewhat falcate, the tip acuminate, the base acute; midrib raised below, impressed above; fine venation more or less flush with the lamina; primary lateral nerves barely larger than the secondary lateral nerves, c. $2-3 \mathrm{~cm}$ apart, diverging at c. $45 \mathrm{x}$; tertiary venation very finely reticulate, especially near the leaf margin; petiole slightly shorter than the blade, sheathing up to the geniculum; sheath membranous, becoming papery fibrous and then falling away; flowering shoots lateral, free, spreading, sympodial; their internodes (except at beginning and end of modules) 2-3 cm long x c. $1 \mathrm{~cm}$ thick; modules initially bearing a prophyll and a few cataphylls the last of which $\mathrm{c} .8 \mathrm{~cm}$ long and mucronate; peduncle ascending, c. $0.8 \mathrm{~cm}$ diam., c. $10 \mathrm{~cm}$ long, subtended by a membranous-winged cataphyll or a leaf with a somewhat reduced blade; spathe broadly ovate, c. $8 \times 8 \mathrm{~cm}$ when flattened, thick, cowl-like, creamy yellow, apiculate; spadix stipitate for c. $1 \mathrm{~cm}$, the fertile part c. $6 \mathrm{~cm}$ long $\times 2 \mathrm{~cm}$, bluntly tapering; flowers c. $2 \mathrm{~mm}$ diam. (larger at the base of the spadix); stamens 4; anthers prominently exserted from between the ovaries, $2.5 \mathrm{~mm}$ long; ovary obpyramidal, c. $3 \mathrm{~mm}$ tall, flat-topped, bearing a style c. $0.6 \mathrm{~mm}$ long with a punctiform stigma; placentation parietal, ovules many, minute; fruit transversely dehiscent with the seeds remaining in the orange mushy fruit base attached to spadix. Figure 1.

DISTRIBUTION: Endemic to regions of tropical eastern Queensland supporting lowland to lower montane rainforest.

The specific epithet commemorates Graeme John Petrie who died in the Sydney AIDS epidemic on December 8th 1991 at the age of thirty-two. In dedicating the discovery of this species to him I am joined by Sylvia Blood, Michael King and Neale Craker, and by Peter Todd and members of the Soma Group.

\section{Rhaphidophora pachyphylla $K$. Krause}

R. pachyphylla K. Krause, Bot. Jahrb. Syst. 49: 92 (1912); Jones \& Gray, Climbing Pl. Australia: 317, un-numbered plate p. 322 (1988). Type: PAPUA New Guinea: Madang Province, Wobbe, Schlechter 16436 (B!, holo).

Distribution: Lowland rainforest in New Guinea and tropical Queensland.

This highly distinctive species is unlikely to be confused with any other Australian aroid.

\section{Rhaphidophora australasica F.M. Bailey}

R. australasica F.M. Bailey, Queensland. Ag. J. 1: 452 (1897) \& Fl. Queensland 5: 1697 (1902); Engler \& Krause in Engler, Pflanzenr. 37 (IV.23.B): 28 (1908); Williams, Native PI. Queensland 1: 252, un-numbered plate (1979); Jones \& Gray, Climbing Pl. Australia: 316, un-numbered plate p. 322 (1988). TYPE: Australia: Queensland: Cairns, Cowley s.n. (BRI!, holo).

DISTRIBUTION: Tropical Queensland in areas supporting lowland and lower montane rainforest. 

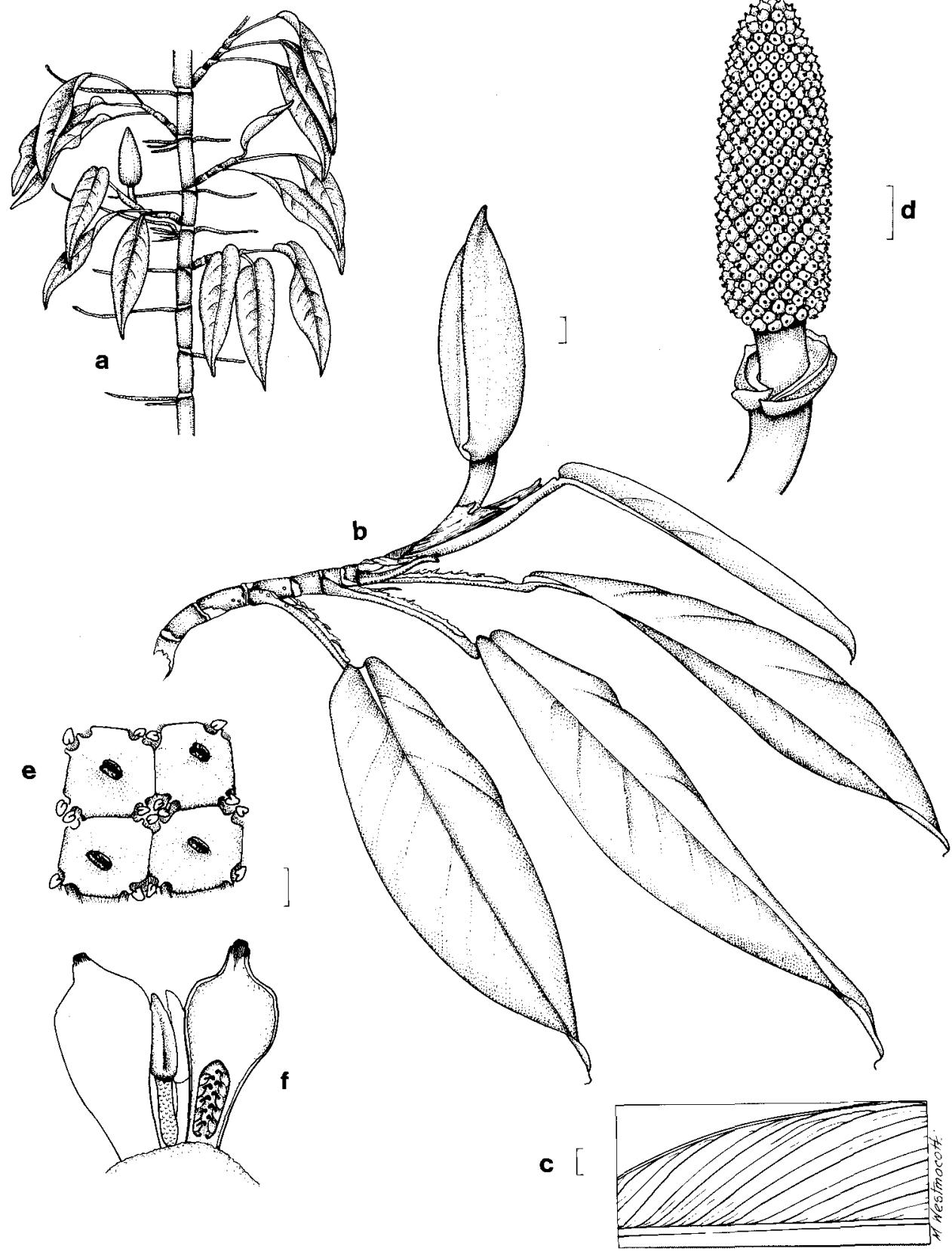

Figure 1. Rhaphidophora petrieana A. Hay. a, habit; $\mathbf{b}$, flowering lateral shoot; $\mathbf{c}$, venation; d, spadix; e, flowers from above; $\mathbf{f}$, pistil in longitudinal section. From a plant growing in the Royal Botanic Gardens Sydney vegetatively propagated from Wrigley \& Telford 43 (CBG!). Scale: $\mathrm{a}$, much reduced; $\mathrm{b}, \mathrm{c}, \mathrm{d}, \mathrm{bar}=1 \mathrm{~cm} ; \mathrm{e}, \mathrm{f}, \mathrm{bar}=1 \mathrm{~mm}$. 
Easily distinguished from $R$. petrieana, with which it has often been confused in herbaria presumably on account of the shared conical style and similar leaf shape, by its differing architecture and its more coriaceous and shiny leaves which are not distinctly paler in colour beneath.

\section{Epipremnum}

Epipremnum Schott, Bonplandia 5: 45 (1857); Engler \& Krause in Engler, Pflanzenr. 37 (IV.23.B): 54 (1908). TYPE: E. mirabile Schott.

\section{Epipremnum pinnatum (L.) Engler}

E. pinnatum (L.) Engler, Pflanzenr. 37 (IV.23.B): 60, fig. 25, plate 1B (1908); Jones \& Gray, Climbing Pl. Australia: 213, un-numbered plate p. 227 (1988). Rhaphidophora pinnata (L.) Schott, Bonplandia 5: 45 (1857); Benth. Fl. Australia 7: 156 (1878); Bailey, Syn. Fl. Queensland: 570 (1883); Williams, Native P1. Queensland 1: 252, unnumbered plate (1979); Pothos pinnata L., Sp. Pl. ed. 2 (1763) 1374. TYPE: Appendix laciniata Rumph., Herb. Amb. 5 (1747) t.183, fig.2 (lecto, vide Nicolson 1979).

Rhaphidophora cunninghamii Schott, Bonplandia 9: 367 (1861). TYPE: Tropical Australia, East Coast, without date, Cunningham s.n. (K!, holo).

Rhaphidophora lovellae Bailey, Queensland Agric. J. 1:453, pl. 6 (1897), Queensland Fl. 5: 1698 (1902). TYPE: AusTRALIA: Queensland: near Cooktown, Lovell s.n. (BRI!, holo).

DisTRIBUTION: widespread through Indomalesia and into Oceania; in Australia known only from rainforest areas of Queensland, with one record as far south as Noosa National Park.

Mature specimens are readily recognised by their pinnatifid leaves. Juveniles can be distinguished from those of other species of Monstereae by the occurrence of longitudinal linear crests in the internodes. Though the leaves are pinnatifid when unfurled, the leaflet tips are linked by a thread of tissue in bud, and the dissection process is intramarginal in ontogeny (Hay \& Mabberley 1991). The seldom-flowering yellow-variegated cultivar 'Aureum' (Nicolson 1978) is very widely grown as an indoor plant, often as 'Scindapsus aureus', 'Pothos aureus' or simply 'Pothos'.

The Cunningham specimen cited above as the type of $R$. cunninghamii is not annotated with this binomial in Schott's hand. However, among Schott's drawings is one of $R$. cunninghamii (Fiche 30 a:2 in the microfiche edition of Schott's 'Icones') exactly resembling this one of the two sterile and fragmentary Cunningham specimens of E. pinnatum at K. I am grateful to D.H. Nicolson for drawing my attention to this illustration.

\section{Epipremnum amplissimum (Schott) Engler}

E. amplissimum (Schott) Engler, Bot. Jahrb. Syst. 1: 182 (1881); Engler \& Krause in Engler, Pflanzenr. 37 (IV.23.B): 59 (1908). Rhaphidophora amplissima Schott, Ann. Mus. Bot. Lugd. Bat. 1: 119 (1863). Type: New GuinEA: Zippelius s.n. (L!, holo).

[Rhaphidophora sp. Williams, Native Pl. Queensland: 252, un-numbered plate (1989). 'Rhaphidophora sp. (Bamaga)' Jones \& Gray, Climbing Pl. Australia: 317, un-numbered plate p. 322 (1988).] 
DistRiBution: New Guinea, the Bismarck Archipelago to Vanuatu; in Australia collected from scattered localities in tropical Queensland and the Northern Territory, in swampy sites or near permanent springs.

Though generally rather more robust in the Melanesian part of the range, Australian representatives are clearly of the same taxon. In open conditions swards of the juvenile stage may form. Juveniles commonly have bluish grey variegation in the lamina and populations occur in which some individuals have non-variegated juveniles (e.g. at Black Jungle swamp, N.T.). This species is readily distinguished from Rhaphidophora australasica, with which it has been confused in herbaria, by its persistent leaf sheath and sessile stigmas, and by the poise of the leaf blade, which tends to be hanging in $R$. australasica and spreading in E. amplissimum. E. amplissimum is sufficiently variable for three entities to have been semi-formally recognized in the horticultural account by Jones \& Gray (1988), of which only that illustrated is cited here.

\section{Scindapsus}

Scindapsus Schott in Schott \& Endlicher, Meletemata Botanica 1: 2 (1832) (emend. in Gen. Aroid. t.81 (1858)); Engler \& Krause in Engler, Pflanzenreich 37 (IV.23.B): 67 (1908). Lectotype [selected by Nicolson in Index Nominum Genericorum 3 (Regnum Vegetabile 102): 1582 (1979)]: S. officinalis (Roxb.) Schott (basionym Pothos officinalis Roxb.).

\section{Scindapsus altissimus Alderw.}

S. altissimus Alderw., Bull. Jard. Bot. Buit. Sér. 3, 4: 346 (1922); Jones \& Gray, Climbing Pl. Australia: 329, un-numbered plate pp. 332 \& 333 (1988). TYPE: NeW GuinEA: near Prauwen Bivak, Lam 1231, 16 Sep 1920 (L!, holo).

Distribution: This immense climber or sprawling lithophyte is widespread in New Guinea in lowland and lower montane rainforests. In Australia it is only recorded from a few localities in the region of Bamaga on the Cape York Peninsula.

\section{Acknowledgements}

I am grateful to the Nissan Motor Company (Australia) who generously supplied a vehicle which enabled field work to be carried out in North Queensland and the Northern Territory in July 1991. I also wish to thank Messrs Clyde Dunlop and Stephen Taylor (NT) and Dr Bernie Hyland (QRS) for assistance with field work. Marion Westmacott supplied the illustration. Dr Simon Mayo kindly sent me xeroxes of pertinent material held at $\mathrm{K}$. The Curators or Directors of the following herbaria made available material held in their institutions: B, BRI, L and QRS. Josef Bogner (München), Dr Dan Nicolson (US) and Karen Wilson (NSW) kindly read and commented on the manuscript.

\section{References}

Bakhuizen van den Brink, R.C. (1958) Are Epipremnum Schott, Rhaphidophora Hassk. and Monstera Adans. congeneric? Blumea Suppl. 4: 91-92.

Blanc, P. (1978) Aspects de la ramification chez les Aracées tropicales. Thèse pour l'obtention du diplôme de Docteur de 3ème cycle à l'Université Pierre \& Marie Curie, Paris. 
Blanc, P. (1981) Observations sur les flagelles des Aracées. Adansonia sér. 2, 20: 325-338.

Bogner, J. \& Nicolson, D.H. (1991) A revised classification of the Araceae with dichotomous keys. Willdenowia 21: 35-50.

Carvell, W.N. (1989) Floral anatomy of the Pothoideae and Monsteroideae (Araceae). Amer. J. Bot. 76 (suppl.): 231.

Engler, A. \& Krause, K. (1908) Araceae-Monsteroideae. Pp. 4-139 in A. Engler (ed.), Das Pflanzenreich 37 (IV.23B). (Engelmann: Leipzig).

Eyde, R.H., Nicolson, D.H. \& Sherwin, P. (1967) A survey of floral anatomy in the Araceae. Amer. J. Bot. 54: 478-497.

French, J.C. (1985) Patterns of endothecial wall thickenings in Araceae subfamilies Pothoideae and Monsteroideae. Amer. J. Bot. 72: 472-486.

French, J.C. (1986) Patterns of stamen vasculature in the Araceae. Amer. J. Bot. 73: 431-449.

French, J.C. (1987a) Systematic survey of resin canals in roots of Araceae. Bot. Gaz. 148: 360-371.

French, J.C. (1987b) Systematic occurrence of a sclerotic hypodermis in roots of Araceae. Amer. J. Bot. 74: 891-903.

French, J.C. (1988) Systematic occurrence of anastomosing laticifers in Araceae. Bot. Gaz. 149: $71-81$.

French, J.C. \& Tomlinson, P.B. (1981) Vascular patterns in stems of Araceae subfamily Monsteroideae. Amer. J. Bot. 68: 1115-1129.

Grayum, M.H. (1984) Palynology and Phylogeny of the Araceae. (University Microfilms International: Ann Arbor).

Grayum, M.H. (1990) Evolution and Phylogeny of the Araceae. Ann. Missouri Bot. Gard. 77: 628697.

Hallé, F. \& Oldeman, R.A.A. (1970) Essai sur l'architecture et la dynamique de croissance des arbres tropicaux. (Masson: Paris).

Hallé, F., Oldeman, R.A.A. \& Tomlinson, P.B. (1978) Tropical trees and forests. An architectural analysis. (Springer: Berlin).

Hay, A. (1986) Cyrtosperma Griff. and the origin of the aroids. Unpublished Doctoral thesis, Oxford University.

Hay, A. (1988) Cyrtosperma (Araceae) and its Old World allies. Blumea 33: 427-469.

Hay, A. (1990) Aroids of Papua New Guinea. (Christensen Research Institute: Madang).

Hay, A. (1992) Tribal and subtribal delimitation and circumscription of the genera of the Araceae tribe Lasieae. Ann. Missouri Bot. Gard. 79: 184-205.

Hay, A. \& Mabberley, D.J. (1991) 'Transference of Function' and the origin of aroids: their significance in early angiosperm evolution. Bot. Jahrb. Syst. 113: 339-428

Jones, D.L. \& Gray, B. (1988) Climbing Plants in Australia. (Reed: Sydney).

Madison, M. (1977) A revision of the genus Monstera. Contr. Gray Herb. 207: 3-100.

Madison, M. \& Tiffney, S. (1976) Seeds of Monstereae: morphology and fossil record. J. Arnold Arbor. 57: 185-201.

Nicolson, D.H. (1960) The occurrence of trichosclereids in the Monsteroideae (Araceae). Amer. J. Bot. 47: 598-612.

Nicolson, D.H. (1968) A revision of Amydrium (Araceae). Blumea 16: 123-127.

Nicolson, D.H. (1978) Araceae. Pp. 345-348 in A.C. Smith (ed.), A precursor to a new flora of Fiji. Allertonia 1: 331-414.

Nicolson, D.H. (1987) Araceae. Pp. 17-101 in M.D. Dassanayake \& F.R. Fosberg (eds.), A revised handbook to the flora of Ceylon. vol. 6. (Amerind: New Delhi).

Ray, T.S. (1987) Diversity of shoot organization in the Araceae. Amer. J. Bot. 74: 1373-1387.

Ray. T.S. (1988) Survey of shoot organization in the Araceae. Amer. J. Bot. 75: 56-84.

Ray, T.S. (1990) Metamorphosis in the Araceae. Amer. J. Bot. 77: 1599-1609. 